\title{
Implementation of Occupational Safety and Health Policies During the Covid-19 Pandemic
}

\author{
Suprianto Suprianto \\ Economic Development \\ Universitas Samawa \\ Sumbawa Besar, Indonesia \\ suprianto@universitas-samawa.ac.id
}

\author{
Vivin Fitryani \\ Banking Finance \\ Universitas Samawa \\ Sumbawa Besar, Indonesia \\ vivinfitryani@universitas-samawa.ac.id
}

\author{
Abdul Rahim \\ Economic Development \\ Universitas Samawa \\ Sumbawa Besar, Indonesia \\ abdulrahim@universitas-samawa.ac.id
}

\author{
Rosyidah Rachman \\ Economic Development \\ Universitas Samawa \\ Sumbawa Besar, Indonesia \\ rosyidahrachman@universitas-samawa.ac.id
}

\author{
Binar Dwiyanto Pamungkas* \\ Economic Development \\ Universitas Samawa \\ Sumbawa Besar, Indonesia \\ binardwiyanto@universitas-samawa.ac.id
}

\begin{abstract}
This is descriptive research. The goal is to describe the implementation of the Occupational Safety and Health (K3) (Research Variable) policy in the Operations and Maintenance of the PT PLN (Persero) UPK Tambora Power Plant during the Covid-19 pandemic. The research data were obtained directly from the main source (not through intermediaries). The sample was determined by purposive sampling, namely 100 people from a total population of 163 people. The research instrument was a questionnaire and the data were obtained in the form of a Likert scale. The results showed that PT PLN (UPK) Tambora had implemented a policy of Occupational Safety and Health (K3) during the coronavirus pandemic (Covid-19) properly. The data comes from the employee perception index which is in the high category with each perception index score of 80.62 for the implementation of occupational safety policies and 84.76 for the implementation of occupational health policies.
\end{abstract}

Keywords: Work Safety, Work Safety, Policy, PT. PLN, Covid-19

\section{INTRODUCTION}

Human resources are a central factor in exploiting natural resources and human resources themselves. All these elements must be maximally utilized, so that the company can seize and expand the market for its products, both in the form of goods and services. Without humans, the company will not run even though capital and technology are available. For this reason, it is very necessary for employees to perform actively in utilizing these resources, so that the company can live and develop.

Humans are the most important factor of production, so there are several aspects related to human resources or employees that must be considered for their quality (knowledge, attitudes, and skills), employee health and condition, needs and welfare of employees, safety, and employee workplace safety. Employee performance improvement will not be possible if the occupational safety and health aspects are not handled in a planned and integrated manner to create and increase the chances of employee work accidents. Health factors greatly influence employee satisfaction [1]. Someone doesn't want to work in a company, if he knows that the company does not guarantee his safety from the dangers and health of his work, even though the company, for example, promises a fairly large salary and adequate facilities and infrastructure. Paramita and Andi Wijayanto, and Firmanzah, et al. found that occupational safety and health have a significant effect on employee performance [2], [3]. Likewise, Wahyuni et al. stated that Occupational Health and Safety (K3) has a significant effect on employee work productivity [4].

Given the important role of labor or human resources in supporting the growth and development of companies, Indonesia has issued policies or regulations in the form of Law Number 13 of 2003 concerning Manpower. One of the points regulated in the law in Article 86 paragraph (1) letter A stated that basically, every worker has the right to get protection for Occupational Safety and Health (K3) [5]. It is further said that to protect worker/labor safety to achieve optimal work productivity, efforts are made to work safety and health. Occupational safety and health efforts are intended to provide safety guarantees and improve the health status of workers/laborers by preventing occupational accidents and diseases, controlling hazards in the workplace, health promotion, treatment, and rehabilitation.

The targets of occupational safety and health are improving employee performance without extorting the workforce and ensuring their productive life. For every company in modern industry, the existence of safety and health must be upheld by the company. Accidents in the company and efforts to prevent them cannot be ignored. This also applies to every company including PT. PLN (Persero) UPK Tambora. As a public company that manages all power generation units and transmission networks on the island of Sumbawa (West Sumbawa Regency, Sumbawa Regency, Dompu Regency, Bima Regency, and Bima City) and employs around 163 workers, the safety and health aspects of employees must be a priority. 
Currently, the safety and health aspects of work are becoming increasingly important for every company to pay attention to in line with the increasing cases of the coronavirus (Covid-19) pandemic that has hit the world including Indonesia, including on the island of Sumbawa, West Nusa Tenggara Province (NTB). The World Health Organization (WHO) states that a coronavirus is a group of viruses that can cause disease in animals or humans. Several types of coronavirus are known to cause respiratory tract infections in humans ranging from cold to more serious coughs such as Middle East Respiratory Syndrome (MERS) and Severe Acute Respiratory Syndrome (SARS). A new type of coronavirus was found to cause Covid-19 disease (Pamungkas, et al., 2020). Based on the press release of the West Nusa Tenggara Province Covid-19 Handling Task Force as of October 31, 2020, the number of Suspect Cases was 12,419, of which 325 people $(3 \%)$ are still in isolation, 65 people $(1 \%)$ are still in probable status, 12,029 people (97\%) already discarded [6].

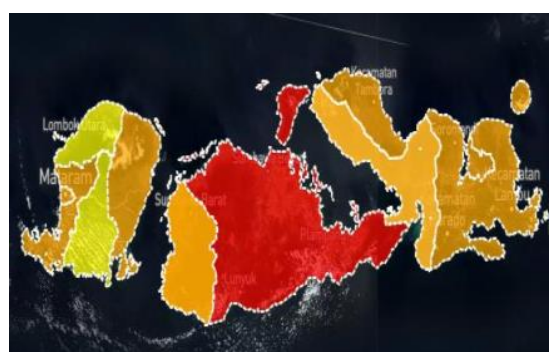

Fig 1. MAP OF COVID-19 Distribution IN West NuSA TengGaRA PROVINCE IN 2020

Based on the picture above, it is known that Sumbawa Regency is an area with a relatively high spread of Covid-19 (in the red zone). Therefore it is important to study the implementation of occupational safety and health policies in companies in the region to provide an overview of the real conditions in the field of the company's readiness to protect human resources or labor during the Covid-19 pandemic.

\section{METHODS}

This is descriptive research. According to Uma Sekaran (2006), a descriptive study was conducted to identify and be able to explain the characteristics of the variables understudy in a situation. Descriptive studies are also carried out to understand the characteristics of organizations that follow certain general practices. The purpose of descriptive studies is to provide a description of the history or to describe aspects relevant to the phenomenon of attention from the perspective of a person, organization, industrial orientation, or other. This study describes the research variables, namely the implementation of Occupational Health and Safety (K3) policies in the Operations and Maintenance of the PT PLN (Persero) UPK Tambora Power Plant during the Covid-19 pandemic. The research data is in the form of primary data obtained directly from the main source (not through intermediaries). The sample was determined by purposive sampling of 100 people from a total population of 163 people. Collecting data using a research instrument in the form of a questionnaire and data obtained in the form of a Likert scale with the answer score category as follows:

- The answer is given a score of 5, the category for the answer is: Strongly Agree (SS)

- The answer is given a score of 4 , the category for the answer is: Agree (S)

- The answer is given a score of 3, the category for the answer is: Less Agree (KS)

- The answer is given a score of 2 , the category is: Disagree (TS)

- Answers are given a score of 1, the categories are: Strongly Disagree (STS)

- The data analysis technique is an index value technique using a scale of 1 to 5 with the following formula.

$((\% \mathrm{~F} 1 \times 1)+(\% \mathrm{~F} 2 \times 2)+(\% \mathrm{~F} 3 \times 3)+(\% \mathrm{~F} 4 \times 4)+(\% \mathrm{~F} 5 \times 5))$

In the next step, the index value is calculated by dividing the accumulated indicator value by the number of scales used. Criteria for range values using three boxes (Tree-Box Method). According to Ferdinand, the Tree Box Method is divided into three categories [7], as follows.

$$
\begin{aligned}
10.00-40.00 & =\text { Low } \\
40.01-70.00 & =\text { Moderate } \\
70.01-100 & =\text { High } \\
\text { III. } & \text { RESULT AND DISCUSSION }
\end{aligned}
$$

\section{RESULT AND DISCUSSION}

\section{A. Implementation of Work Safety Policies}

The results of the measurement of the perception index of the implementation of occupational safety policies consist of 9 indicators including, 1). The company is very concerned about the safety aspects of employees (80.60, high category), 2). Workers/employees are given information dissemination on how to use the materials, tools, and machines used regarding the identification, assessment, and control of occupational accident and disease risks (84,80, high category), 3). workers/employees are always given directions on how to identify the hazards that threaten at work and how to prevent incidents $(84,60$, high category), 4). The company reacts quickly and precisely to deviant conditions that threaten work safety (80,40, high category), 5). Workers/employees know exactly how to use safety equipment when on duty (85.00, high category), 6). The safety standards set by the company ensure safe conditions (81,80, high category), 7$)$. Every employee who violates work safety regulations is given a sanction (85.80, high category), 8). The company provides standard work equipment (79.00, high category), 9). the company provides personal protective equipment following standards (safety helmets, safety shoes, wear packs, safety glasses, safety gloves, and full body harness) $(81,60$, high category).

The results of the data analysis above show that the average index of employees' perceptions of the 
implementation of work safety policies at PT. PLN (Persero) UPK Tambora amounting to 80.62 with the high category. This means that the company maintains and guarantees the safety of its employees so that employees feel safe while working. Various efforts have been made by the company as a form of work safety policy implementation, namely socialization to employees on how to use materials, tools, and machines used regarding identification, assessment, and control of work-related accident risks, providing directions to employees on how to identify hazards that threaten at work and how to prevent incidents, provide prompt and appropriate reactions to deviant conditions that threaten work safety, provide work equipment and standard personal protective equipment, and impose sanctions on employees who violate work safety regulations. Preventing work accidents is the main thing to protect employee safety and create a sense of security for employees while working. The existence of a sense of security at work will certainly have an impact on employee performance for the better so that it is profitable for the company.

\section{Implementation of Occupational Health Policy}

The results of measuring the employee perception index related to the implementation of occupational health consist of 5 indicators including 1). The company always pays attention to the health aspects of its employees (81.60, high category), 2). Health facilities provided by the company including health insurance already exist (86.60, high category), 3). The company determines the number of hours worked following applicable regulations (87.40, high category), 4). Companies provide adequate rest time when employees are recovering from illness $(82,20$, high category), 5). Periodic health examination of workers/employees (86.00, high category).

The results of the data analysis above show that the average index of employees' perceptions of the implementation of work safety policies at PT. PLN (Persero) UPK Tambora amounted to 84.76 with a high category. This also means that the company pays close attention to the health aspects of employees so that employees feel comfortable at work. Various efforts have been made by the company as a form of implementation of occupational health policies, namely health facilities provided by the company including health insurance (health insurance), determining the number of working hours following applicable regulations, providing adequate rest time when employees are recovering from illness, and employee/employee health checks periodically every year. Guaranteed employee health will provide a sense of comfort for employees while working. Having a sense of comfort at work will certainly have an impact on employee performance for the better so that it is profitable for the company.

The spread of the coronavirus has limited various activities, but some people still have to work to run the wheels of the economy. Therefore, so that every workforce or employee can work safely, the implementation of occupational safety and health (K3) becomes an important aspect during the coronavirus pandemic (Covid-19) as work risks increase, which must be ensured by every company. The International Labor Organization or ILO (2020) mentions "safe and healthy working conditions as the basis for decent work". This is even more important today, given the importance of ensuring workplace safety and health in pandemic management and the ability to return to work.

PT PLN (Persero) UPK Tambora as a public company has implemented a K3 policy to ensure the safety and health of employees during the current Covid-19 pandemic. The implementation of $\mathrm{K} 3$ is considered to be able to encourage company performance to remain good even during a pandemic. Implementation of K3 by PT. PLN (Persero) UPK Tambora is in line with the International Social Security Association (ISSA) program. ISSA pays very serious attention to the implementation of $\mathrm{K} 3$, especially during a pandemic. ISSA set global vision zero in 2017 as the principle for social security administrators. This consists of three aspects, namely safety, health, and well-being at work which means welfare at all levels of work. The principle of global vision zero is in line with the $\mathrm{K} 3$ principles that already exist in Indonesia. The implementation of global vision zero has a positive impact on the economy. This happens because healthy working conditions can also contribute to a healthy business [8].

Based on observations, PT PLN (Persero) UPK Tambora has also implemented health protocols in its work environment, for example by requiring employees to wear masks, maintain distance (social distancing), and wash their hands in response to the Circular of the Minister of Manpower of the Republic of Indonesia Number M / 7 / As 02.02 / V / 2020 the Year 2020 concerning Business Continuity Plans in Facing the 2019 Corona Virus Disease Pandemic (Covid-19) and the Covid-19 Transmission Prevention Protocol in Companies. The implementation of health protocols is also in line with the list of Covid-19 Prevention and Mitigation in the Workplace issued by the [9].

Given that the Covid-19 pandemic is predicted to be still going on for a long time and it is not known when it will end, in addition to the things that have been done above, it is no less important that the company must do and implement a Business Continuity Plan in Facing the Covid-19 Pandemic as mandated by the Minister of Manpower based on the Circular of the Minister of Manpower of the Republic of Indonesia Number M / 7 / As.02.02 / V / 2020 of 2020. Ferial (2020) explained the making of this business continuity plan is intended so that business actors can identify and Minimizing risks that can affect business activities due to the Covid-19 virus by preparing strategies to reduce the impact of this pandemic. It is hoped that this work plan can be adjusted according to the guidelines of local government and must be communicated to all business actors and workers.

The stages of activities for the Preparation of Business Continuity Planning in the Face of the Covid-19 Pandemic under the Circular of the Minister of Manpower of the Republic of Indonesia Number M / 7 / As.02.02 / V / 2020 of 2020, as follows: Stage 1: Identifying Business Priorities: (a) Determining the main products/services of the business, by identifying and making a ranking based on 
the level of importance; (b) Identifying activities or activities that are essential from the main product/service that has been determined; (c) Identifying staff/workers who are responsible for handling essential activities/activities that have been previously identified for the essential activities/activities.

Stage 2: Identification of Pandemic Risk. Identification. The risk assessment must be carried out as a team by considering three important components, namely: (a) Identification of possible threat scenarios; (b) Vulnerability analysis of business activities; (c) Analysis of the company's capability.

Stage 3: Planning for Risk Mitigation. (a) Developing Standard Operating Procedures (SPO); (b) Develop a flexible work plan; (c) Ensure that the supply chain has a preparedness plan and that supply goods are free from Covid-19; (d) Empowering facilities, institutions or work units and human resources in the company; (e) Reviewing the company's HR policies (e.g., sick leave, travel, compensation, overtime, etc.) (f) Implementation of Occupational Safety and Health (K3) with measures to prevent transmission in the workplace.

Stage 4: Identification of Pandemic Impact Responses. The company undertakes specific response measures tailored to the situation with the development of the pandemic, by (a) Ensuring workers understand the efforts to prevent transmission; (b) Ensuring customers and suppliers know that the company is ready and able to face a pandemic; (c) Make use of the communication team to convey the necessary information, especially to customers and suppliers.

Stage 5: Designing and Implementing Business Continuity Planning. This is done by combining all information and compiling a business continuity plan that includes the entire company's operating scheme.

Stage 6: Communicating Business Continuity Planning. (a) Conduct internal and external outreach related to planning (b) Share information about the readiness of business continuity planning with internal parties (workers and management); (c) Share information about the readiness of business continuity planning with external parties (customers, suppliers, and others).

Stage 7: Conducting Business Continuity Planning Tests. Test the plans that have been prepared for improving the plan. Testing of a plan must be carried out regularly to always be able to identify new problems and formulate solutions.

\section{CONCLUSION}

PT PLN (UPK) Tambora has implemented a policy of Occupational Safety and Health (K3) during the coronavirus pandemic (Covid-19) properly. This is evident from the employee perception index which is in the high category with each perception index score of 80.62 for the implementation of occupational safety policies and 84.76 for the implementation of occupational health policies.

\section{ACKNOWLEDGMENT}

Thank you to the management of PT. PLN (Persero) UPK Tambora and LPPM Samawa University for their cooperation and have helped researchers in data collection.

\section{REFERENCES}

[1] S. Suprianto, R. Masniadi, Y. Hartono, D. Mardhia, and I. W. Ayu, "Hygiene Factor and Its Effects on Employee Satisfaction of PT. PLN (Persero) UPK Tambora," Indones. J. Soc. Sci. Humanit., vol. 1, no. 2, pp. 77-86, 2020.

[2] C. C. P. Paramita and A. Wijayanto, "Pengaruh keselamatan dan kesehatan kerja terhadap prestasi kerja karyawan pada pt. Pln (persero) apj semarang," J. Adm. Bisnis, vol. 1, no. 1, 2012.

[3] A. Firmanzah, D. Hamid, and M. Djudi, "Pengaruh Keselamatan Dan Kesehatan Kerja Terhadap Kinerja Karyawan (Studi Pada Karyawan PT. PLN (Persero) Area Kediri Distribusi Jawa Timur)," J. Adm. Bisnis, vol. 42, no. 2, pp. 1-9, 2017.

[4] N. Wahyuni, B. Suyadi, and W. Hartanto, "Pengaruh Keselamatan Dan Kesehatan Kerja (K3) Terhadap Produktivitas Kerja Karyawan Pada Pt. Kutai Timber Indonesia," J. Pendidik. Ekon. J. Ilm. Ilmu Pendidikan, Ilmu Ekon. Dan Ilmu Sos., vol. 12, no. 1, pp. 99-104, 2018.

[5] DEWAN PERWAKILAN RAKYAT REPUBLIK INDONESIA, "UNDANG-UNDANG REPUBLIK INDONESIA NO.13 TAHUN 2003 TENTANG," Jakarta, Mar. 2003. Accessed: May 11, 2021. [Online]. Available: https://www.ilo.org/dyn/natlex/docs/ELECTRONIC/64764/71 554/F1102622842/IDN64764.pdf.

[6] Pemerintah Daerah NTB, “COVID-19 NTB," Provinsi NTB, 2020. https://corona.ntbprov.go.id/ (accessed May 11, 2021).

[7] A. Ferdinand, "Metode Penelitian Manajemen, Badan," Penerbit Univ. Diponegoro. Semarang, 2012.

[8] Wibi Pangestu Pratama, "Penerapan Keselamatan dan Kesehatan Kerja Bisa Dorong Pertumbuhan Ekonomi Finansial Bisnis.com," https://finansial.bisnis.com/, Nov. 2020.

https://finansial.bisnis.com/read/20201013/215/1304281/pener apan-keselamatan-dan-kesehatan-kerja-bisa-dorongpertumbuhan-ekonomi (accessed May 11, 2021).

[9] International Labour Organization, "Manajemen Konflik Dan Bencana: Dalam menghadapi pandemi," 2020. Accessed: May 11, 2021. [Online]. Available: https://www.ilo.org/. 